Published in final edited form as:

Org Lett. 2018 October 05; 20(19): 6170-6173. doi:10.1021/acs.orglett.8b02652.

\title{
Total Synthesis of Asperphenins A and B
}

\author{
Jia-Lei Yan ${ }^{a}$, Yingying Cheng ${ }^{a}$, Jing Chen ${ }^{a}$, Ranjala Ratnayake ${ }^{b, c}$, Long H. Dang ${ }^{b, c, d}$, \\ Hendrik Luesch ${ }^{\mathrm{b}, \mathrm{c}}$, Yian Guo ${ }^{\mathrm{a},{ }^{*},}$ Tao Ye ${ }^{\mathrm{a},{ }^{*}}$ \\ aState Key Laboratory of Chemical Oncogenomics, Key Laboratory of Chemical Genomics, \\ Peking University Shenzhen Graduate School, Xili, Nanshan District, Shenzhen, 518055, China; \\ bepartment of Medicinal Chemistry, University of Florida, Gainesville, Florida 32610, United \\ States
}

${ }^{\circ}$ Center for Natural Products, Drug Discovery and Development (CNPD3), University of Florida, Gainesville, Florida 32610, United States

${ }^{\mathrm{d} D e p a r t m e n t}$ of Medicine, University of Florida, Gainesville, Florida 32610, United States

\begin{abstract}
The first total synthesis of asperphenins $\mathrm{A}$ and $\mathrm{B}$ has been accomplished in concise, highly stereoselective fashion from commercially available materials (15 steps, $9.7 \%$ and $14.2 \%$ overall yields, respectively). The convergent route featured the judicious choice of protecting groups, fragment assembly strategy and a late-stage iron-catalyzed Wacker-type selective oxidation of an internal alkene to the corresponding ketone.
\end{abstract}

\section{Graphical Abstract}<smiles></smiles>

Asperphenin A (1) : 17R; Asperphenin B (2) : 17S

\footnotetext{
*Corresponding Author: yet@pkusz.edu.cn; bryan_pku@qq.com.

Supporting Information

The Supporting Information is available free of charge on the ACS Publications website at DOI:

Experimental details and data (PDF)

The authors declare no competing financial interest.
}

Metabolites isolated from marine fungus often possess unique structural features and incorporate new or unusual assemblages of functional groups. Many of them provide novel lead molecules for probing fundamental biological processes and the development of novel 
chemotherapeutic agents that target cancers. Our laboratory is engaged in a program devoted to the total synthesis and evaluation of marine natural products. ${ }^{[1]}$ Herein, we disclose the first total synthesis of asperphenins A and B by utilizing a highly efficient and convergent approach.

Asperphenins A and B (Scheme 1) were isolated from a culture broth of marine-derived Aspergillus sp. collected from the shore of Jeju Island, Korea. ${ }^{[2]}$ The relative and absolute stereochemical configuration of asperphenins had been established by a combination of spectroscopic analyses, chemical degradation, Mosher ester analysis, CD measurements and ECD calculations. Structurally, these two natural products are comprised of a $\beta$-hydroxy fatty acid, a tripeptide and a trihydroxybenzophenone. Asperphenins A and B exhibit significant cytotoxicity against several human cancer cell lines, e.g. with $\mathrm{IC}_{50}$ values of 0.8 and $1.1 \mu \mathrm{M}$ respectively against RKO colorectal carcinoma cells.

Scheme 1 outlines our retrosynthetic analysis plan. We anticipated that the condensation of acid $\mathbf{3}$ with either fragment $\mathbf{4}$ or $\mathbf{5}$ followed by removal of protecting groups would give rise to the natural products. We envisioned the amine moiety of $\mathbf{4}$ or $\mathbf{5}$ could arise from either asymmetric Mannich reaction of ketone $6 \mathbf{a}$ or a stereoselective Wittig olefination of aldehyde $\mathbf{6 b}$ with a leucinol-derived triphenylphosphonium salt. Both $\mathbf{6 a}$ and $\mathbf{6 b}$, in turn, could be accessed from a reaction of aryl iodide $\mathbf{8}$ with lactols $\mathbf{7 a}$ and $\mathbf{7 b}$, respectively.

The synthesis of fragment $\mathbf{3}$ commenced with the known compound $\mathbf{9},{ }^{[3]}$ which underwent titanium tetrachloride mediated enatioselective aldol reaction with caprinaldehyde to provide $\mathbf{1 0}^{[4]}$ as a single diastereomer in $81 \%$ yield (Scheme 2). Protection of the resulting alcohol as its TBS ether followed by hydrolytic cleavage of the chiral auxiliary furnished the acid $\mathbf{1 1}$ in $76 \%$ yield. In parallel, coupling of $N$-Cbz- $L$-asparagine and $L$-glutamine methyl ester under the influence of HATU in the presence of HOAt and DIPEA furnished the corresponding dipeptide, which was subjected to hydrogenolysis of the $\mathrm{Cbz}$ protecting group to produce amine 14 in 76\% yield over two steps. A second HATU/HOAt-mediated condensation of acid 11 and amine 14 provided the corresponding amide 15 in $85 \%$ yield. Saponification of the methyl ester with $\mathrm{LiOH}$ in aqueous methanol followed by acidification afforded the acid 3 in $81 \%$ yield.

Our planned first approach to asperphenin A required the synthesis of fragment 4 from ketone 6a via an asymmetric Mannich reaction (Scheme 3). Thus, 2-methoxy-4methylbenzoic acid $\mathbf{1 6}$ was converted into the corresponding acid chloride and then coupled with $N, N$-diethyl amine to afford $\mathbf{1 7}$ in $95 \%$ yield. Regioselective formylation of $\mathbf{1 7}$ to aldehyde 18 was achieved through an amide-directed ortho-lithiation (tert-BuLi, TMEDA) followed by quenching with DMF (86\% yield). ${ }^{[5]}$ Addition of methylmagnesium bromide to aldehyde 18 afforded the corresponding secondary alcohol, which was immediately subjected to acid-promoted lactonization to give rise to $\mathbf{1 9}$ in $92 \%$ yield over 2 steps. ${ }^{[5 b, 6]}$ Lactone 19 was treated with boron tribromide in dichloromethane to produce the crude deprotected phenol, which was then re-protected by benzylation using benzyl bromide and potassium carbonate to afford the benzyl derivative $\mathbf{2 0}$ in $81 \%$ yield. Partial reduction of the lactone 19 using DIBAL-H at $-78{ }^{\circ} \mathrm{C}$ furnished the corresponding lactol $7 \mathbf{a}$ as a latent hydroxyaldehyde in 95\% yield. Spurred by Knochel's seminal findings on halogen- 
magnesium exchange, ${ }^{[7]}$ we opted to convert the readily available aryl iodide $\mathbf{8}$ to the corresponding arylmetal species with $i$-PrMgCl$\cdot \mathrm{LiCl}$, followed by the addition of lactol $7 \mathbf{a}$ to give rise to biphenyl diol $\mathbf{2 1}$ as a mixture of diastereomers in $85 \%$ yield. Ley's TPAP oxidation ${ }^{[8]}$ of 21 delivered the corresponding diketone $6 \mathbf{a}$ in $78 \%$ yield and set the stage for the exploration of the key asymmetric Mannich reaction. ${ }^{[9]}$ However, this reaction proved to be challenging due to the high propensity of trapping of the transient enolate intramolecularly with an electrophile. Accordingly, treatment of methyl ketone $\mathbf{6 a}$ and tertbutanesulfinyl imine 22 with various bases, solvent, and concentrations at low temperature, resulted in no observation of the desired product. For example, while exposure of both $\mathbf{6 a}$ and $\mathbf{2 2}$ in the presence of one equivalent of potassium hexamethyldisilazane (KHMDS), two aldol products (23 and $\mathbf{2 4}$ ) were obtained (Scheme 3). Given that the reactions afforded $\beta$ amino ketone $\mathbf{2 3}$ as the major product, we reasoned that the asymmetric Mannich reaction occurred with simultaneous cyclization of the regenerated enolate onto the ketone to afford the thermodynamically more stable product.

To circumvent the problems encountered in above strategy toward the construction of chiral amine 4 via an asymmetric Mannich reaction, we turned our attention to the strategy where the ketone moiety would have to be installed at a later stage of the synthesis. Thus, aldehyde 18 was transformed into lactone $\mathbf{2 5}$ by a two-step sequence involving (1) reduction with sodium borohydride and (2) acid-promoted lactonization (Scheme 4). Lactone $\mathbf{2 5}$ was then elaborated to the lactol $\mathbf{7 b}$ in $81 \%$ yield by an identical strategy as described for $\mathbf{7 a}$, including methyl ether deprotection and reprotection of the resulting free phenol with benzyl bromide and potassium carbonate, followed by partial reduction of the lactone with DIBAL$\mathrm{H}$ at $-78^{\circ} \mathrm{C}$. Again, the Grignard reagent derived from aryl iodide 8 added to lactol $\mathbf{7 b}$ provided biphenyl diol 27 in $72 \%$ yield. To our surprise, use of the previously employed Ley's TPAP oxidation of diol 27 led to the dicarbonyl product $\mathbf{6 b}$ in $27 \%$ yield along with the over-oxidation product 28 (58\%). Similar results were obtained with manganese dioxide $^{[11]}$ in dichlorometane. 2,3-Dichloro-5,6-dicyano-1,4-benzoquinone (DDQ) ${ }^{[12]}$ oxidation of the benzylic alcohols in $\mathbf{2 7}$ provided intractable mixtures with nodesired products. Gratifyingly, treatment of diol 27 with PCC on alumina ${ }^{[13]}$ in DCM smoothly afforded the desired aldehyde $\mathbf{6 b}$ in $76 \%$ yield as the sole product.

In parallel, $D$-leucinol (29) was transformed into trifluoroacetamide 30 by a three-step sequence involving (1) trifluoroacetylation of the primary amine; (2) conversion of the alcohol into the bromide with $\mathrm{CBr}_{4}$ and $\mathrm{Ph}_{3} \mathrm{P}$; (3) the $\beta$-Amino phosphonium salt formation upon treating the resulting bromide with triphenyl phosphine in refluxing toluene. Wittig reaction of aldehyde $\mathbf{6 b}$ with the phosphorane derived from phosphonium bromide $\mathbf{3 0}$ was next examined. Thus, treatment of the phosphonium salt $\mathbf{3 0}$ with 2.1 equivalent of $n$-butyl lithium followed by addition of the aldehyde $\mathbf{6 b}$ delivered the alkene $\mathbf{3 1}$ enriched in the desired $E$-isomer $(E / Z=5: 1) .{ }^{[14]}$ The desired product $\mathbf{3 1}$ could be isolated free of the Z isomer in $77 \%$ yield by chromatography on silica gel. The presence of the trifluoroacetamide in $\mathbf{3 0}$ ensured the generation of the dianion intermediate, which presumably played a critical role to the stereochemical outcome of this transformation. [14b, 15] Hydrolysis of the trifluoroacetamide $\mathbf{3 1}$ gave allylic amine $\mathbf{5}$ in nearly quantitative 
yield. Acetylation of amine $\mathbf{5}$ was achieved under basic conditions with acetyl chloride to afford $\mathbf{3 2}$ in $82 \%$ yield. (Scheme 5)

With alkenes $\mathbf{3 1}$ and $\mathbf{3 2}$ in hand, the stage was set to explore the crucial Wacker-type oxidation. Attempts to selectively oxidize the $E$-alkenes $\mathbf{3 1}$ and $\mathbf{3 2}$ using molecular iodine or $N$-iodosuccinimide ${ }^{[16]}$ gave little or no desired products (Table 1, entries 1-4). The literature precedents suggested that Wacker oxidation of cinnamyl azides ${ }^{[17 a]}$ and 2-

styryltetrahydro-2H-pyrans ${ }^{[17 b]}$ occurred predominantly or exclusively at the benzylic rather than the homobenzylic carbon. Attempted Wacker oxidation of both $\mathbf{3 1}$ and 32, however, delivered only trace quantities of the desired ketone. As we searched for alternative methods of transforming alkenes $\mathbf{3 1}$ and $\mathbf{3 2}$ into ketones 33a and 33b, we were drawn to a report by Han and co-workers of a mild variant of the Wacker-type oxidation. ${ }^{[18]}$ In the Han modification of the Wacker oxidation, iron(II) chloride, polymethylhydrosiloxane and air were employed as a highly efficient and selective catalytic system. Because the mild oxidation conditions enable exceptional functional-group tolerance, we tested this protocol with alkene 31. We were pleased to discover that the iron-catalyzed Wacker-type oxidation of alkene 31 provided ketone 33a in 30\% yield. To our delight, the same iron-catalyzed aerobic oxidation of $\mathbf{3 2}$ delivered $\mathbf{3 3 b}$ in $89 \%$ yield. (Table 1, entries 7,8 ).

Encouraged by the successful transformation of alkene $\mathbf{3 2}$ to the corresponding $\beta$-ketone amide $\mathbf{3 3 b}$, we proceeded with the total synthesis of asperphenin A and B as outlined in Schemes 6 and 7. Thus, coupling of acid $\mathbf{3}$ and allylic amine $\mathbf{5}$ under the influence of EDCI in the presence of HOAt and DIPEA afforded 34 in $71 \%$ yield. After removal of the TBS group to give rise to the corresponding alcohol $\mathbf{3 5}$, which was then subjected to an ironcatalyzed Wacker oxidation to furnish $\mathbf{3 6}$ in $85 \%$ yield. The final global hydrogenative debenzylation went on without incident to provide asperphenin A in $72 \%$ yield. (Scheme 6) To this end, we synthesized ent $\mathbf{5}$ following the same synthesis as for $\mathbf{5}$, but starting with $L$ leucinol. This was readily achieved, and ent $\mathbf{5}$ was incorporated into the synthesis as previously performed to afford asperphenin B with no adverse consequences. (Scheme 7) The spectral data for synthetic 1 and $2\left({ }^{1} \mathrm{H},{ }^{13} \mathrm{C}\right.$ NMR and HMRS) were identical with those published for the natural products, and the optical rotation of our products, $\left([a]_{\mathrm{D}}{ }^{25}-22.0, c\right.$ $0.1, \mathrm{MeOH}$, for asperphenin $\mathrm{A} ;[a]_{\mathrm{D}}{ }^{25}-16.2, c 0.1, \mathrm{MeOH}$, for asperphenin $\mathrm{B}$ ), corresponded well with the literature value, (lit. $[a]_{\mathrm{D}}{ }^{25}-24.7, c 0.1, \mathrm{MeOH}$, for asperphenin $\mathrm{A} ;[a]_{\mathrm{D}}{ }^{25}-18.4, c 0.1, \mathrm{MeOH}$, for asperphenin $\mathrm{B}$ ), leading us to conclude that synthetic $\mathbf{1}$ and $\mathbf{2}$ were of the same absolute stereochemistry as natural asperphenins A and B.

With the synthetic asperphenins A (1) \& B (2) in hand, the screening of cytotoxic activities toward a number of cancer cell lines has been investigated (Figure 1). The initial cytotoxicity evaluation of $\mathbf{1}$ and $\mathbf{2}$ was performed across a panel of the HIF dependent HCT116 colorectal cancer cell lines using isogenic (HCT116 ${ }^{H I F-1 a-/-H I F-2 a-/-}$ and HCT116 WT KRAS ) knock out cells to identify if these compounds preferentially target HIF/KRAS pathways. Both compounds were only moderately cytotoxic against parental HCT116 with reduced cytotoxicityagainst the human normal colon cells, CCD-18Co. ${ }^{[10]}$ Asperphenin A (1) shows a 2-fold decrease in potency against HCT116 ${ }^{H I F-1 a-/-H I F 2 a-/-}\left(\mathrm{IC}_{50}\right.$ shifts from $2.2 \mathrm{uM}$ to $5.1 \mathrm{uM}$ ) with simultaneous decrease in efficacy. For cells lacking oncogenic KRAS 
(HCT116 ${ }^{W T K R A S}$ ) only a slight decrease in total efficacy was observed compared to the parental HCT116 cell line. ${ }^{[10]}$ Asperphenins may have a slight selectivity for colon cancer cells over normal cells that could be explored further with SAR studies.

In summary, stereocontrolled total synthesis of asperphenins A and B has been accomplished through combination of the judicious choice of protecting groups, a fragment assembly strategy and a late-stage iron-catalyzed Wacker-type selective oxidation of an internal alkene to the corresponding ketone. Both of the synthetic samples exhibit interesting results in preliminary biological assays.

\section{Supplementary Material}

Refer to Web version on PubMed Central for supplementary material.

\section{ACKNOWLEDGMENT}

We acknowledge financial support from the Shenzhen Peacock Plan (KQTD2015071714043444); the NSFC (21772009), the SZSTIC (JCYJ20160527100424909), (JCYJ20170818090017617), (JCYJ20170818090238288) and the GDNSF (2014B030301003), the National Institutes of Health, NCI grant R01CA172310, the Debbie and Sylvia DeSantis Chair professorship (H.L.) and NCI Research Specialist Award R50CA211487 (R.R)

\section{REFERENCES}

1. (a)Al-Awadhi FH; Gao B; Rezaei MA; Kwan JC; Li C; Ye T; Paul VJ; Luesch HJ Med. Chem 2018, 61, 6364.;(b)Guo Y; Zhao M; Xu Z; Ye T Chem. Eur. J 2017, 23, 3572.; [PubMed: 28152222] (c)Zhou J; Gao B; Xu Z; Ye TJ Am. Chem. Soc 2016, 138, 6948.(d)Gunasekera SP; Li Y; Ratnayake R; Luo D; Lo J; Reibenspies JH; Xu Z; Clare-Salzler MJ; Ye T; Paul VJ; Luesch H Chem. Eur. J 2016, 22, 8158. [PubMed: 27139508] (e)Qu S; Chen Y; Wang X; Chen S; Xu Z; Ye T Chem. Commun 2015, 51, 2510.(f)Lei H; Yan J; Yu J; Liu Y; Wang Z; Xu Z; Ye T Angew. Chem. Int. Ed 2014, 53, 6533.

2. Liao L; Bae SY; Won TH; You M; Kim S-H; Oh D-C; Lee SK; Oh K-B; Shin J Org. Lett 2017, 19, 2066. [PubMed: 28387122]

3. Kitir B; Baldry M; Ingmer H; Olsen CA Tetrahedron 2014, 70, 7721.

4. (a)Yadav JS; Dachavaram SS; Grée R; Das S, Tetrahedron Lett 2015, 56, 3999.(b)Yadav JS; Rajendar G; Ganganna B; Srihari P Tetrahedron Lett 2010, 51, 2154.

5. (a)Snieckus V Chem. Rev 1990, 90, 879.(b)Li Z; Gao Y; Tang Y; Dai M; Wang G; Wang Z; Yang Z Org. Lett 2008, 10, 3017. [PubMed: 18553973]

6. Brimble MA; Flowers CL; Hutchinson JK; Robinson JE; Sidford M Tetrahedron 2005, 61, 10036.

7. (a)Knochel P; Dohle W; Gommermann N; Kneisel FF; Kopp F; Korn T; Sapountzis I; Vu VA Angew. Chem. Int. Ed 2003, 42, 4302.(b)Krasovskiy A; Knochel P Angew. Chem. Int. Ed 2004, 43, 3333.(c)Krasovskiy A; Straub BF; Knochel P Angew. Chem. Int. Ed 2005, 45, 159.

8. Saha T; Maitra R; Chattopadhyay SK Beilstein J. Org. Chem 2013, 9, 2910. [PubMed: 24454570]

9. (a)Babij NR; Wolfe JP Angew. Chem. Int. Ed 2012, 51, 4128.(b)Davis FA; Yang B Org. Lett 2003, 5, 5011. [PubMed: 14682752] (c)Tang TP; Ellman JA J. Org. Chem 2002, 67, 7819. [PubMed: 12398509]

10. For the details, please check the supporting Information

11. (a)Hollinshead SP; Nichols JB; Wilson JW J. Org. Chem 1994, 59, 6703.(b)Srivastava AK; Panda G Chem.- Eur. J 2008, 14, 4675.

12. (a)Torricelli F; Bosson J; Besnard C; Chekini M; Bürgi T; Lacour J Angew. Chem. Int. Ed 2013, 52, 1796.;(b)Bosson J; Labrador GM; Pascal S; Miannay F-A; Yushchenko O; Li H; Bouffier L; Sojic N; Tovar RC; Muller G; Jacquemin D; Laurent AD; Guennic BL; Vauthey E; Lacour J Chem. Eur. J 2016, 22, 18394. [PubMed: 27885721] 
13. Flanagan SR; Harrowven DC; Bradley M Tetrahedron 2002, 58, 5989.

14. (a)Andersson IE; Dzhambazov B; Holmdahl R; Linusson A; Kihlberg JJ Med. Chem 2007, 50, 5627.(b)Wiktelius D; Luthman K Org. Biomol. Chem 2007, 5, 603. [PubMed: 17285166]

15. Maryanoff BE; Reitz AB; Duhl-Emswiler BA J. Am. Chem. Soc 1985, 107, 217.

16. Harikrishna K; Mukkamala R; Hinkelmann B; Sasse F; Aidhen IS Eur. J. Org. Chem 2014, 2014, 1066.

17. (a)Carlson AS; Calcanas C; Brunner RM; Topczewski JJ Org. Lett 2018, 20, 1604.; [PubMed: 29498865] (b)Keinan E; Seth KK; Lamed RJ Am. Chem. Soc 1986, 108, 3474.

18. (a)Liu B; Jin F; Wang T; Yuan X; Han W Angew. Chem. Int. Ed 2017, 56, 12712.(b)Han W; Liu B Synlett 2018, 29, 383.

Org Lett. Author manuscript; available in PMC 2020 July 02. 

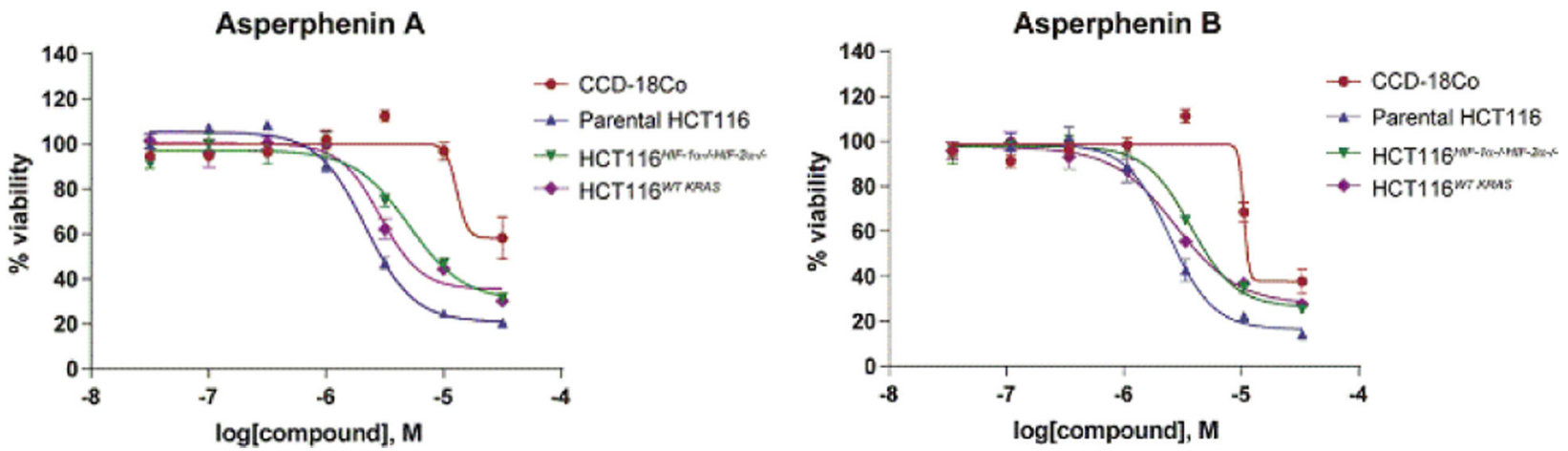

Figure 1.

Effect of Asperphenin A (1) and B (2) on isogenic HCT116 colon cancer cells and normal colon cells. 


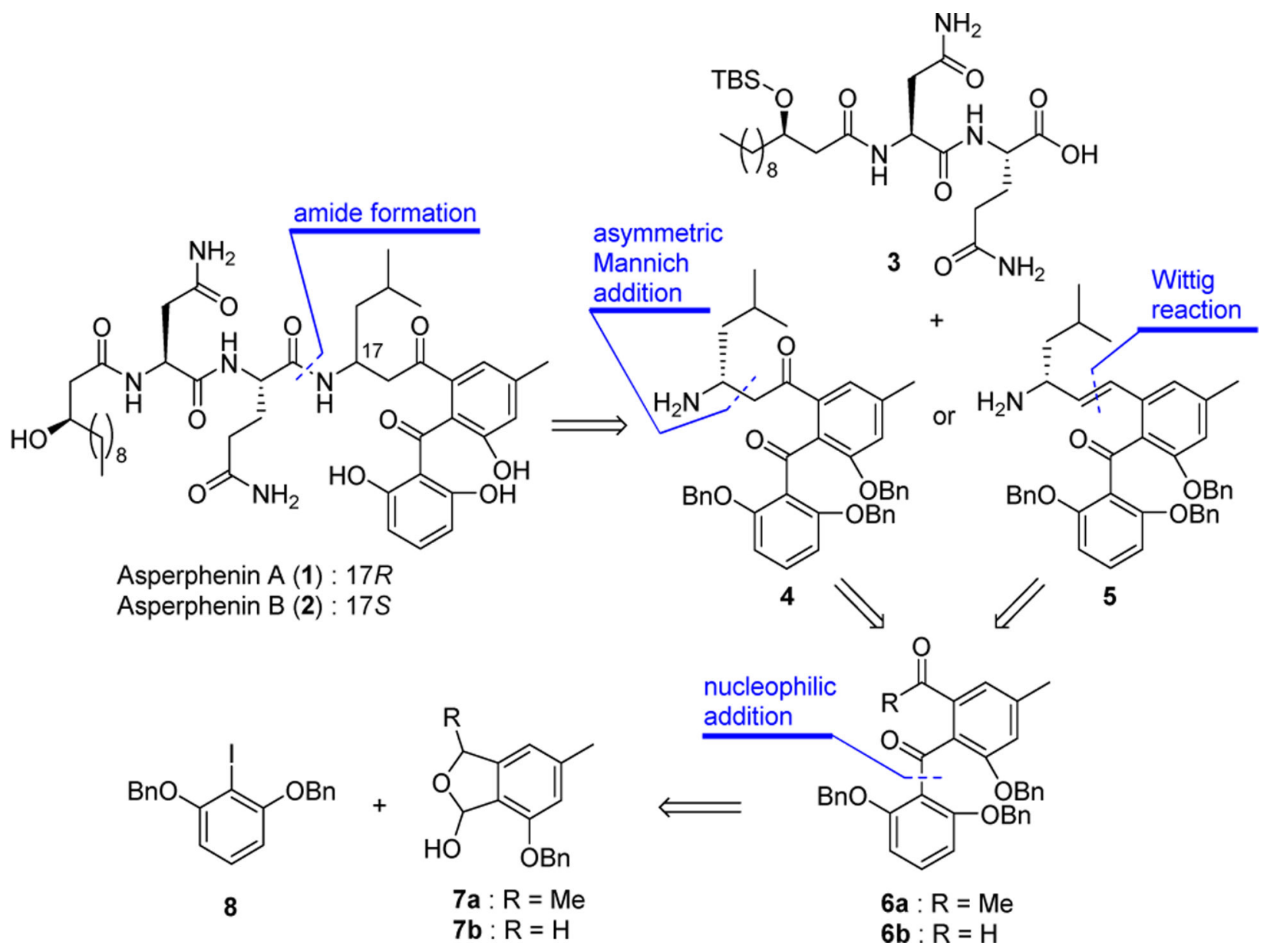

Scheme 1.

Retrosynthetic Analysis of Asperphenin A 
<smiles>CC(=O)N1C(=S)SC[C@H]1Cc1ccccc1</smiles><smiles></smiles>

1) TBSOTf 2,6-lutidine TBS $\stackrel{\mathrm{DCM}, 0^{\circ} \mathrm{C}}{\longrightarrow}$

2) $\mathrm{LiOH} \cdot \mathrm{H}_{2} \mathrm{O}$

$\mathrm{THF} / \mathrm{H}_{2} \mathrm{O}$ $76 \%$ for 2 steps<smiles>O=C(O)C[C@@H](O[Sn])C1CCCC1</smiles><smiles>COC(=O)[C@H](N)CCC(N)=O</smiles>

1) HATU, HOAt DIPEA, DMF 2) $\mathrm{Pd} / \mathrm{C}, \mathrm{H}_{2}, \mathrm{MeOH}$ $76 \%$ for 2 steps

12<smiles>CC1(C)CC[C@@H]1CC(=O)N[C@@H](CC(N)=O)C(=O)N[C@H](CCC(N)=O)C(=O)O</smiles><smiles></smiles>

Scheme 2.

Synthesis of Fragment $\mathbf{3}$<smiles>CCCC(NC(=O)[C@H](N)CC(N)=O)[C@H](CCC(N)=O)C(=O)OC</smiles> 


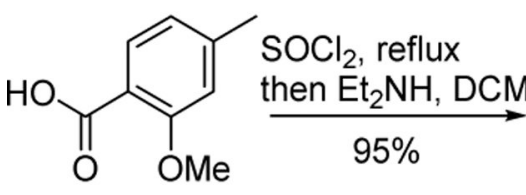

16

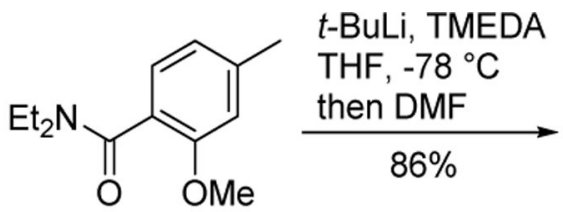

17<smiles>CCNC(=O)c1c(C=O)cc(C)cc1OC</smiles>

18

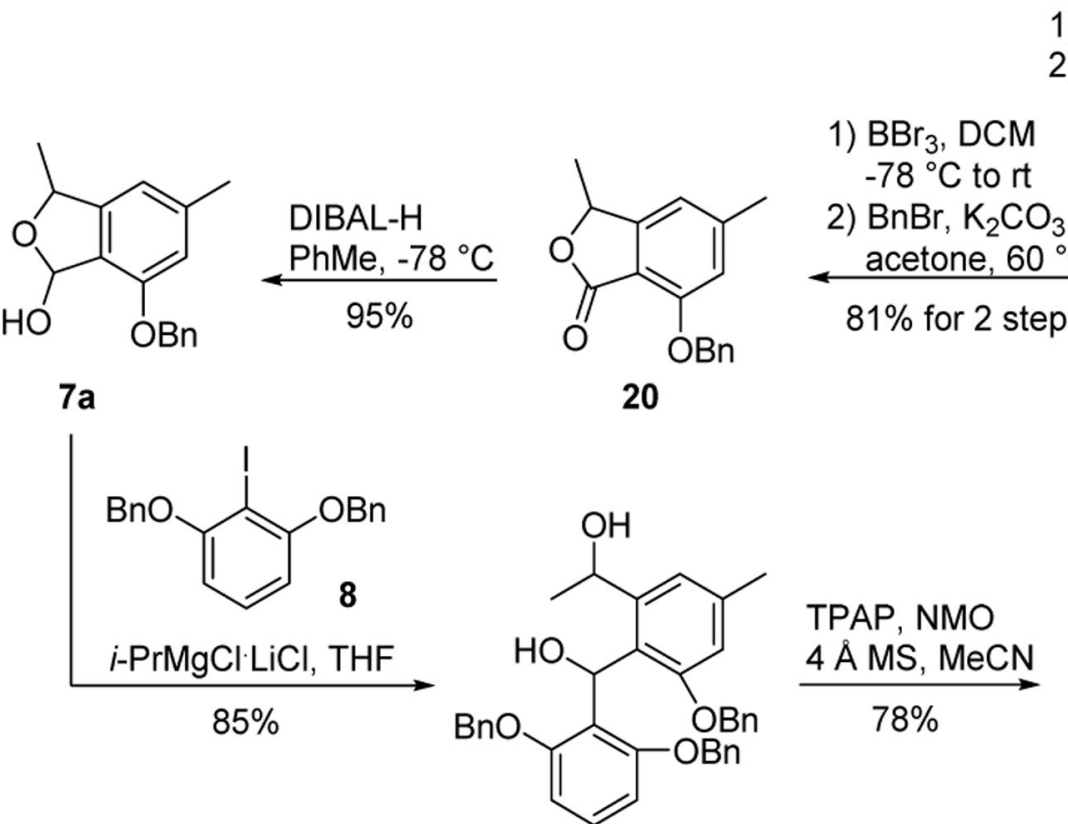

21<smiles>Cc1cc(C(=O)c2ccccc2)c2c(c1)C(=O)C([C@H](CC(C)C)N[S@]([O-])(O)C(C)(C)C)C2(O)c1c(O)cccc1Cc1ccccc1</smiles>

23

$86 \%$<smiles>Cc1cc(Br)c2c(c1)C(=O)CC2(O)c1c(OCc2ccccc2)cccc1OCc1ccccc1</smiles>

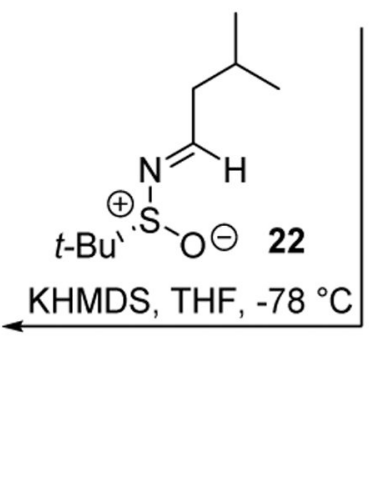

1) $\mathrm{MeMgBr}, \mathrm{THF} 92 \%$ for

2) PTSA, PhMe reflux 2 steps<smiles>COc1cc(C)cc2c1C(=O)OC2C</smiles>

19<smiles>CC(=O)c1cc(C)cc(OCc2ccccc2)c1C(=O)c1c(OCc2ccccc2)cccc1OCc1ccccc1</smiles>

$6 a$

Scheme 3

Attempts on the Synthesis of Intermediate 4 
1) $\mathrm{NaBH}_{4}$ $\mathrm{THF} / \mathrm{MeOH}$<smiles>CCNC(=O)c1c(C=O)cc(C)cc1OC</smiles>

18<smiles>COc1cc(C)cc2c1C(=O)OC2</smiles>

25
1) $\mathrm{BBr}_{3}, \mathrm{DCM}$ $-78^{\circ} \mathrm{C}$ to $\mathrm{rt}$ 2) $\mathrm{BnBr}, \mathrm{K}_{2} \mathrm{CO}_{3}$ acetone, $60{ }^{\circ} \mathrm{C}$ $83 \%$ for 2 steps O OBn<smiles>Cc1cc2c(c(OCc3ccccc3)c1)C(O)OC2</smiles><smiles>Cc1cc(C=O)c(C(=O)c2c(O)cccc2OCc2ccccc2)c(OCc2ccccc2)c1</smiles><smiles>CCCCc1cc(C)cc(CO)c1C(O)c1c(OCc2ccccc2)cccc1OCc1ccccc1</smiles>

Scheme 4.

Synthesis of Aldehyde $\mathbf{6 b}$ 


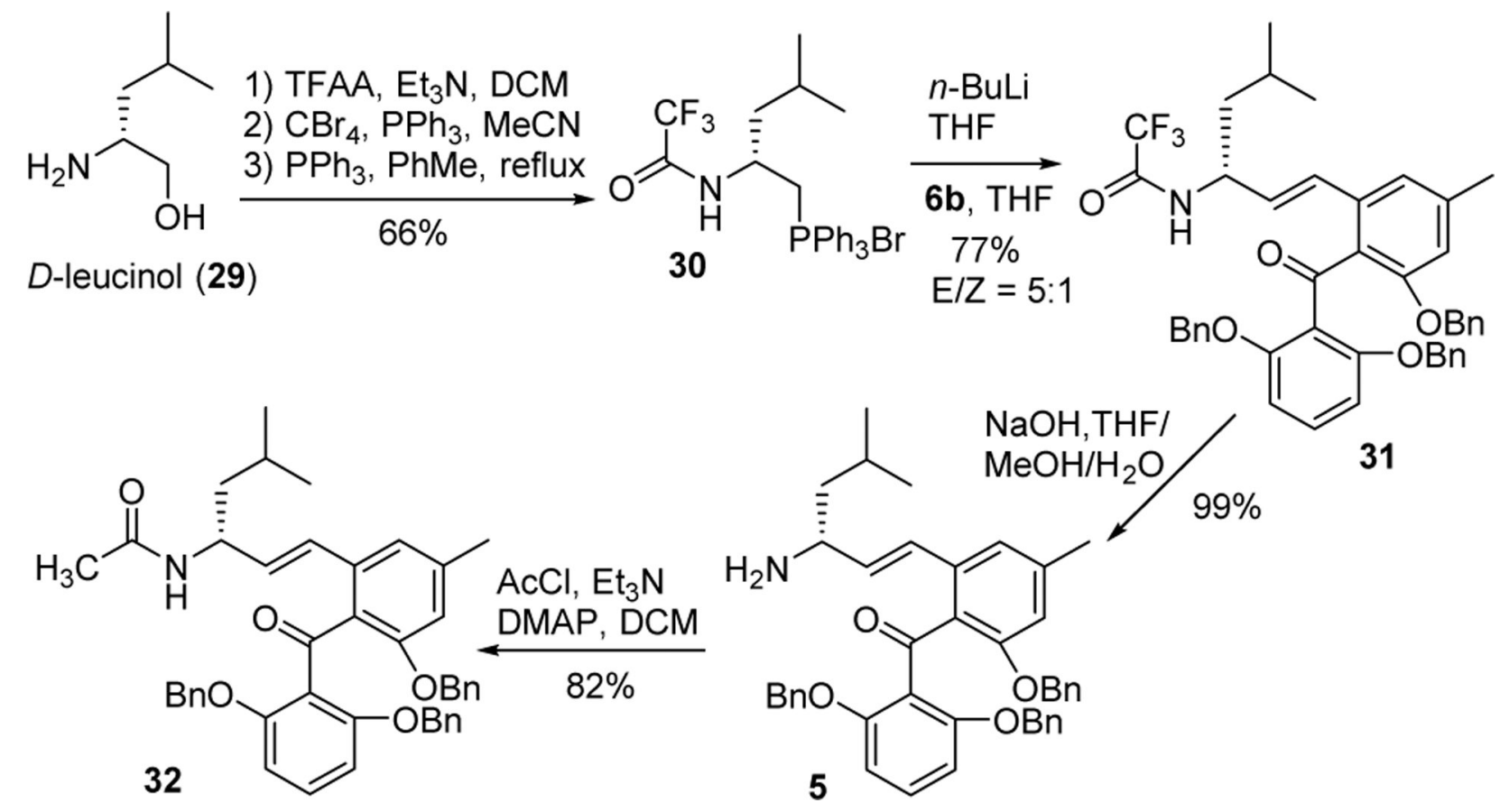

Scheme 5.

Synthesis of Amine 5 and Amides 31, 32 
<smiles>Cc1cc(Br)c(C(=O)c2c(OCc3ccccc3)cccc2OCc2ccccc2)c(/C=C/[C@H](N)CC(C)C)c1</smiles>

5
3, EDCl, HOAt $71 \%$

TBAF, THF, $87 \%$

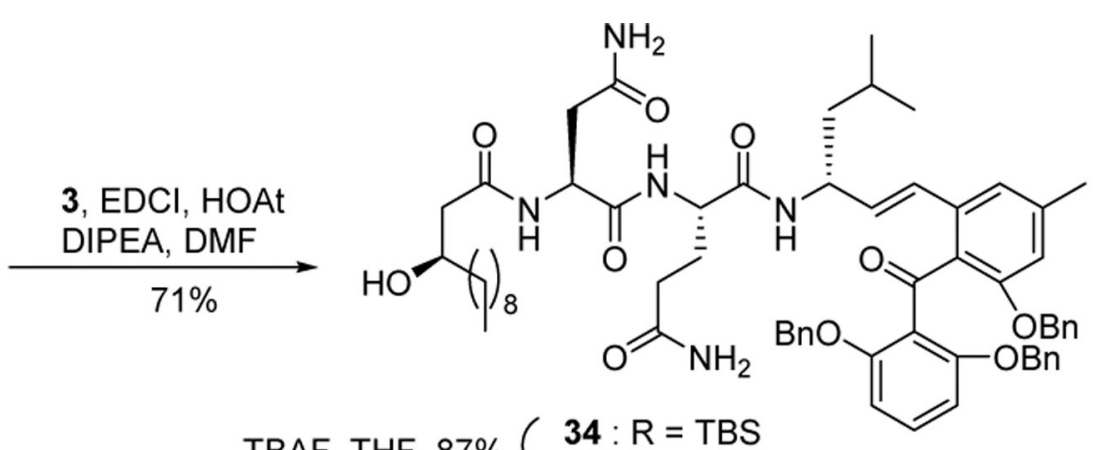

$35: \mathrm{R}=\mathrm{H}$

$\mathrm{FeCl}_{2}, \mathrm{PMHS}$

$\mathrm{EtOH}$, air, $80{ }^{\circ} \mathrm{C} \downarrow 85 \%$

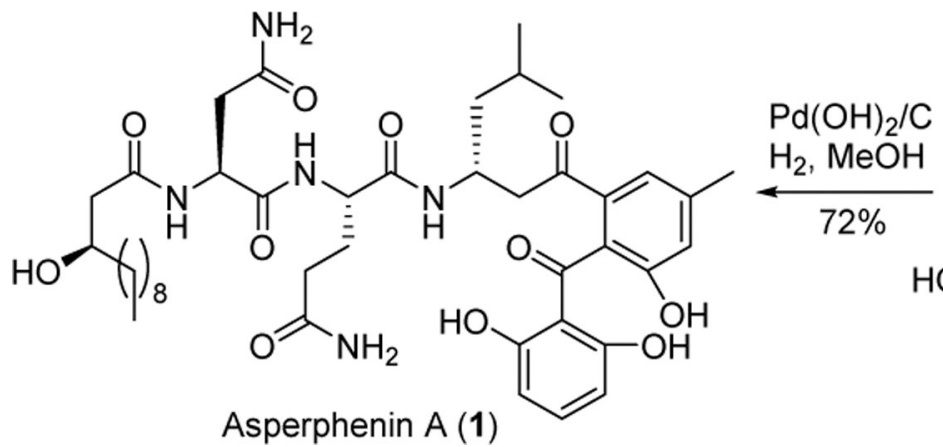<smiles></smiles>

Scheme 6.

Synthesis of Asperphenin A 
<smiles>C#CCOc1cccc(OCc2ccccc2)c1C(=O)c1c(/C=C/C(N)CC(C)C)cc(C)cc1OCc1ccccc1</smiles><smiles>Cc1cc(O)c(C(=O)c2c(O)cccc2O)c(C(=O)C[C@@H](CC(C)C)NC(=O)[C@H](CCC(N)=O)NC(=O)[C@H](CC(N)=O)NC(=O)C[C@@H]2CC[13CH]CC[C@@H]2O)c1</smiles>

Asperphenin B (2)

Scheme 7.

Synthesis of Asperphenin B 
Table 1.

Optimization of the Wacker-type Oxidation

\begin{tabular}{ccccc} 
condition & $\boldsymbol{t}^{\mathbf{0}}$ & yield \\
\hline 1 & $\mathbf{3 1}$ & 90 & $\mathrm{~N} . \mathrm{D}$. \\
2 & $\mathbf{3 2}$ & $\mathrm{I}_{2}$, dioxane $/ \mathrm{H}_{2} \mathrm{O}$ & 90 & $\mathrm{~N} . \mathrm{D}$. \\
3 & $\mathbf{3 1}$ & $\mathrm{NIS}_{2}$, dioxane $/ \mathrm{H}_{2} \mathrm{O}$ & 30 & trace \\
4 & $\mathbf{3 2}$ & $\mathrm{NIS}_{2}$, dioxane $/ \mathrm{H}_{2} \mathrm{O}$ & 30 & trace \\
5 & $\mathbf{3 1}$ & $\mathrm{PdCl}_{2}, \mathrm{CuCl}, \mathrm{O}_{2}, \mathrm{H}_{2} \mathrm{O}, \mathrm{DMF}$ & 50 & trace \\
6 & $\mathbf{3 2}$ & $\mathrm{PdCl}_{2}, \mathrm{CuCl}, \mathrm{O}_{2}, \mathrm{H}_{2} \mathrm{O}, \mathrm{DMF}$ & 50 & trace \\
7 & $\mathbf{3 1}$ & $\mathrm{FeCl}_{2}, \mathrm{PMHS}, \mathrm{EtOH}$, air & 80 & $30 \%$ \\
8 & $\mathbf{3 2}$ & $\mathrm{FeCl}_{2}, \mathrm{PMHS}, \mathrm{EtOH}$, air & 80 & $89 \%$ \\
\hline
\end{tabular}

